\title{
Perancangan Model Optimasi Penggunaan Energi Pada Gedung SD Plus Gembala Baik Pontianak
}

\author{
Mega Sulastri ${ }^{1)}$, Triasih Aritonang ${ }^{2)}$ \\ ${ }^{1,2)}$ Magister Teknik Elektro Fakultas Teknik Universitas Tanjungpura Pontianak, \\ ${ }^{1)}$ Staf Pengajar SD Plus Gembala Baik Pontianak \\ ${ }^{2)}$ Ka.Sub.Bag Keuangan dan Kepegawaian Fakultas Teknik Untan \\ e-mail : mega_sulastri@yahoo.com,trie_ft@yahoo.com
}

\begin{abstract}
Kondisi pencahayaan dan udara yang nyaman merupakan hal yang mutlak dalam suatu ruangan namun tidak boleh meninggalkan aspek penghematan energi listrik. Lingkungan belajar fisik adalah keadaan berbentuk fisik berada di sekitar tempat belajar yang dapat mempengaruhi siswa secara langsung maupun tidak langsung. Banyak faktor yang membentuk lingkungan belajar fisik dan berpengaruh terhadap produktivitas belajar diantaranya adalah suhu dan intensitas cahaya. SD Plus GembalaBaik merupakan tempat pembelajaran dasar yang dimana setiap ruang kelas menggunakan energy listrik khususnya untuk lampu penerangan dan pendingin udara yang aktif selama 8 jam rata-rata setiap harinya, dimulai pukul 07.00 sampai dengan pukul 15.00. Selama ini penggunaan energi listriknya belum terkontrol pemakaiannya dalam memenuhi Standar Nasional Indonesia (SNI). Dari hal tersebut dilakukan penelitian dengan membuat pemodelan matematis dari hasil pengukuran dan perhitungan menggunakan metode optimasi (Program Linier) guna mengefisiensi pemakaian energi listriknya. Pertama, dilakukan pengambilan data existing penggunaan lampu dan $A C$ kemudian dibandingkan dengan Standar Nasional Indonesia (SNI) yang dijadikan acuan pembuatan pemodelan optimasi. Dari hasil pengukuran diperoleh bahwa suhu dan kelembaban udara pada ruang kelas sudah optimal dan sesuai Standar Nasional Indonesia (SNI) sehingga tidak dilanjutkan kepemodelan optimasi. Sedangkan untuk pencahayaan terdapat kelebihan sebesar 15.353 lumen. Pada pemodelan yang dibuat jumlah lampu yang dipakai lebih besar atau sama dengan 36.684,7 lumen dan daya kurang dari 233,2 Watt. Dari hasil pengukuran dan pemodelan disarankan untuk menggunakan lampu Shinyoku sebanyak 5 buah lampu dengan 45 Watt dan 7 buah lampu dengan 65 Watt dan meletakkan posisi lampu sesuai yang disarankan untuk menghemat energi.
\end{abstract}

Keywords- Optimasi, program linear

\section{Pendahuluan}

Lingkungan belajar fisik adalah keadaan berbentuk fisik berada di sekitar tempat belajar yang dapat mempengaruhi siswa secara langsung maupun tidak langsung. Banyak faktor yang membentuk lingkungan belajar fisik dan berpengaruh terhadap produktivitas belajar diantaranya adalah suhu dan intensitas cahaya.
Dimana telah diketahui penerangan dan suhu dihasilkan oleh perangkat listrik (lampu dan pendingin udara) yang menggunakan energi listrik sebagai sumbernya. Sumber energi listrik saat ini kebanyakan masih menggunakan sumber listrik dengan bahan baku fosil, yang mana telah diketahui bahwa bahan baku tersebut semakin menipis keberadaannya.

SD Plus Gembala Baik merupakan tempat pembelajaran dasar yang dimana setiap ruang kelas menggunakan energi listrik khususnya untuk lampu penerangan dan pendingin udara yang aktif selama 8 jam rata-rata setiap harinya dimulai dari pukul 07.00 sampai dengan pukul 15.00. Selama ini penggunaan energi listriknya belum terkontrol pemakaiannya dalam memenuhi Standar Nasional Indonesia (SNI), sehingga perlu dilakukannya penelitian meliputi pengukuran dan perhitungan pemakaian energi listriknya serta perancangan optimasi konsumsi energi.

Dari hal tersebut di atas akan dilakukan penelitian dengan membuat pemodelan matematis dari hasil pengukuran dan perhitungan menggunakan metode optimasi (Program Linier) guna mengefisiensi pemakaian energi listriknya.

\section{Tinjauan Pustaka}

\subsection{Sistem Penerangan}

Suatu penerangan diperlukan oleh manusia untuk mengenali suatu objek secara visual. Penerangan dapat memanfaatkan sumber cahaya alami yang berasal dari matahari maupun sumber buatan manusia. Jika penerangan alami dirasa cukup maka tidak diperlukan penerangan buatan. Namun penerangan untuk didalam ruangan biasanya tidaklah cukup hanya dengan menggunakan sumber cahaya alami saja, oleh karena itu diperlukannya sumber penerangan buatan.

\subsubsection{Cahaya}

Cahaya merupakan suatu bentuk energi yang diradiasikan atau dipancarkan dari sebuah sumber dalam bentuk gelombang dan merupakan bagain dari keseluruhan kelompok gelombang-gelombang elektromagnet. Panjang gelombang adalah jarak antara punak-puncak gelombang energi. Cahaya alami dari matahari atau lampu wolfram sering disebut sebagai cahaya putih dan terdiri dari campuran spektrum dari semua cahaya pelangi ${ }^{[3]}$. 
2.1.2 Discomfort Glare (Silau yang menyebabkan ketidaknyamanan melihat)

Tingkat ketidaknyamanan ini tergantung pada luminansi dan ukuran sumber silau, luminansi latar belakang dan posisi sumber silau terhadap medan penglihatan. Discomfort glare akan semakin besar jika suatu sumber mempunyai luminansi yang tinggi, ukuran yang luas, luminansi latar belakang yang rendah dan posisi yang dekat dengan garis penglihatan. ${ }^{[5]}$

\subsubsection{Aliran Cahaya}

Aliran rata-rata energi cahaya adalah arus cahaya atau fluksi iluminasi (F) yang dipancarkan oleh sumber di ukur dalam lumen. Satu lumen adalah fluksi cahaya yang dipancarkan dalam sudut pejal satuan dari sebuah titik sumber sebesar 1 lilin $^{[3]}$. Sedangkan menurut Muhaimin "Arus cahaya juga didefinisikan sebagai jumlah total cahaya yang dipancarkan oleh sumber cahaya setiap detik",[4].

\subsubsection{Kuat Penerangan ( Illumination ) dan kesehatan Mata}

Kuat penerangan adalah kuantitas atau jumlah cahaya pada level pencahayaan per luas permukaan tertentu [Satuan $=$ lux $\left(\right.$ lumen $\left./ \mathrm{m}^{2}\right)$ ]. Iluminasi $(E)$ adalah cahaya yang jatuh pada sebuah permukaan ${ }^{[3]}$. Standart kuat penerangan dalam kelas adalah 250 lux sesuai SNI 03-2396-2001. Dengan tetap mematuhi standar tersebut dan mengantisipasi depresiasi dari lampu, maka dalam penelitian ini ditetapkan kuat penerangan rata-rata yang ingin dicapai adalah minimum 250 lux.

\subsubsection{Kuat Penerangan yang merata}

Kuat penerangan yang merata adalah penting karena tiga hal, yaitu (1) dapat mengurangi variasi kuat penerangan dalam ruang dengan aktivitas sejenis; (2) kepadatan cahaya dapat mempengaruhi kinerja dan kenyamanan visual; (3) pencahayaan yang tidak merata tidak memuaskan secara subjektif. ${ }^{[6,7,8]}$

\subsubsection{Reflektansi}

Skala reflektansi cahaya adalah antara 0 dan $100 \%$, hitam ke putih. Jika ada berbagai jenis permukaan yang berbeda, reflektansi diambil nilai rata-ratanya, angka reflektansi untuk kelas agar didapat kenyamanan penglihatan. ${ }^{[8,9]}$

\subsubsection{Hubungan Kuat Penerangan dengan Angka Reflektansi}

Warna terang memantulkan lebih banyak cahaya daripada warna gelap. Nilai CU paling dominan bergantung pada reflektansi permukaan; dengan demikian, reflektansi permukaan yang lebih tinggi berarti nilai $\mathrm{CU}$ yang lebih tinggi. Jadi, bila angka reflektansi permukaan ditingkatkan, nilai CU juga harus tinggi, sehingga kuat penerangan juga meningkat. ${ }^{[8,9]}$

\subsubsection{Penerangan Ruang Kelas}

Pada saat merencanakan penerangan dalam ruangan yang harus diperhatikan pertama kali adalah kuat penerangan, warna cahaya yang diperlukan, dan arah pencahayaan sumber penerangan. Kuat penerangan ruangan dikategorikan menjadi 6 , yaitu: ${ }^{[4]}$

a) Penerangan ekstra rendah, dibawah 50 lux.

b) Penerangan rendah, dibawah 150 lux.

c) Penerangan sedang, 150 hingga 175 lux.

d) Penerangan tinggi:

(1) Penerangan tinggi I, 200 lux

(2) Penerangan tinggi II, 300 lux

(3) Penerangan tinggi III, 450 lux

e) Penerangan sangat tinggi, 700 lux.

f) Penerangan ekstra tinggi, di atas 700 lux

Penerangan yang digunakan untuk ruang kelas termasuk penerangan untuk keperluan umum. Berdasarkan sistem pancaran cahaya dari sumber cahaya penerangan pada ruang kelas merupakan penerangan setengah langsung. ${ }^{[4]}$

\subsubsection{Faktor Pemeliharaan (Light Loss Factor, LLF)}

Debu dan kotoran pada penerangan dan umur dari lampu itu sendiri juga dapat mengurangi keluaran cahaya. Penerangan akan terganggu oleh kondisi dekorasi ruangan yang buruk. Suatu angka sebesar 0,8 lazim digunakan untuk faktor pemeliharaan tetapi harus dikurangi untuk lingkungan yang berdebu dan kotor seperti pada ruangan pengerjaan kayu. Namun pada ruangan dan armatur dengan pemeliharaan yang baik pada umumnya koefisien depresiasinya diambil sebesar $0,8 .^{[3]}$

\subsubsection{Perhitungan dan Alat Ukur Kuat} Penerangan
$\mathrm{k}$ menghitung kuat penerangan dapat Untuk menghitung kuat penerangan dapat
menggunakan rumus sebagai berikut: $:^{[4]}$

$$
\mathrm{E}=\frac{\varphi \times \mathrm{CU}}{\mathrm{A}}
$$

dimana :

$\mathrm{E}=$ rata-rata penerangan (lux)

$\varphi=$ total fluks pencahayaan pada area pencahayaan

( lumen )

$\mathrm{CU}=$ koefisien utilitas

$\mathrm{A}=$ luas area pencahayaan $\left(\mathrm{m}^{2}\right)$

Adanya depresiasi akibat debu pada armature, maka persamaan tersebut harus dikalikan dengan suatu LightLoss Factor (LLF) sebagai berikut :

$$
\mathrm{E}=\frac{\varphi \times \mathrm{CU} \times \mathrm{LLF}}{\mathrm{A}}
$$

Dinyatakan lebih jelas dengan, ${ }^{[4]}$

$$
\mathrm{E}=\frac{\mathrm{N} \times \mathrm{n} \times \mathrm{LL} \times \mathrm{CU} \times \mathrm{LLF}}{\mathrm{A}}
$$

dimana :

$\mathrm{N}=$ jumlah armature (buah)

$\mathrm{n}=$ jumlah lampu tiap armature (buah)

LL = lumen yang dihasilkan tiap lampu (lumen)

Dari persamaan (2-3), maka nilai E bergantung pada faktor $\varphi, \mathrm{CU}, \mathrm{LL}, \mathrm{LLF}$ dan A. Faktor $\varphi=(\mathrm{N} \times \mathrm{n})$ menunjukkan besarnya tingkat pencahayaan dari sumber 
cahaya, yang berkaitan dengan jumlah lampu, besar nya inisial lumen dari lampu, dan jumlah armatur. LLF menunjukan faktor pemeliharaan yang meliputi: Lamp Lumen Depreciation (LLD), Luminaire Dirt Depreciation (LDD) dan Room Surface Dirt Depreciation (RSDD), faktor CU menunjukkan bagian tertentu dari cahaya total yang sampai dibidang kerja (the level of interest) berkaitan dengan distribusi cahaya oleh titik cahaya, ketinggian titik cahaya diatas bidang kerja, proporsi ruang, dan reflektansi permukaan.

\subsubsection{Tingkat Pencahayaan Minimum yang Direkomendasikan}

Tingkat pencahayaan ruangan dapat dibedakan menurut penggunaannya. Berikut adalah beberapa tingkat pencahayaan minimum yang direkomendasikan untuk berbagai fungsi ruangan ditunjukkan pada Tabel $2 .^{[3]}$

Tabel 1. Tingkat Pencahayaan Minimum yang direkomendasikan

\begin{tabular}{cc}
\hline Fungsi Ruangan & Tingkat Pencahayaan (lux) \\
\hline Ruang kelas & 250 \\
Perpustakaan & 300 \\
Laboratorium & 500 \\
\hline
\end{tabular}

\subsection{Daya Listrik}

Daya Listrik didefinisikan sebagai laju hantaran energi listrik dalam rangkaian listrik.Satuan SI daya listrik adalah Watt (W) yang menyatakan banyaknya tenaga listrik yang mengalir per satuan waktu (Joule/detik).

Arus listrik yang mengalir dalam rangkaian dengan hambatan listrik menimbulkan kerja.

Daya listrik, seperti daya mekanik, dilambangkan oleh huruf $P$ dalam persamaan listrik ${ }^{[9]}$

$$
\mathrm{P}=\mathrm{V} \times \mathrm{I}
$$

dimana :

$$
\begin{aligned}
& \mathrm{P}=\operatorname{daya}(\mathrm{W}) \\
& \mathrm{I}=\operatorname{arus}(\mathrm{A}) \\
& \mathrm{V}=\operatorname{perbedaan} \operatorname{potensial}(\mathrm{V})
\end{aligned}
$$

\section{Metodologi Penelitian}

\subsection{Lokasi Penelitian}

Penelitian ini akan dilakukan pada ruang kelas SD Plus Gembala Baik Pontianak sebagai ruang percontohan (pilot study). SD Plus Gembala Baik Pontianak merupakan salah satu sekolah dasar yang ada di Pontianak yang memiliki gedung dengan 4 lantai dengan 14 ruang, 1 ruang kepala sekolah , 1 ruang guru , 1 ruang tata usaha dan 1 ruang laboratorium komputer.

\subsection{Diagram Alir Penelitian}

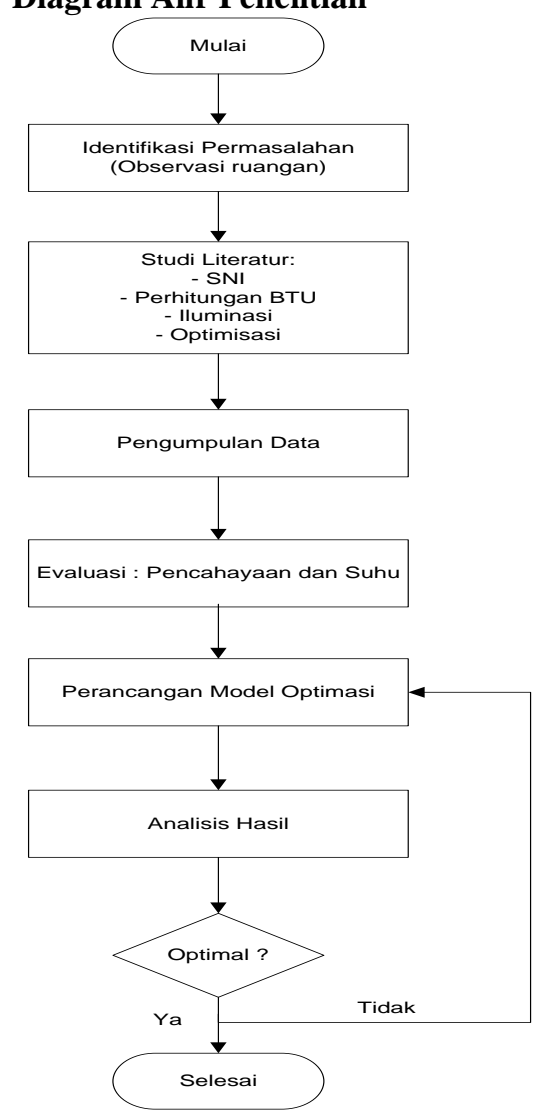

4. Analisa dan Hasil

\subsection{Hasil Pengukuran Ruang Sampel menggunakan Tang ampere}

Berdasarkan hasil pengukuran konsumsi arus beban lampu pada ruangan kelas menggunakan tang ampere sebesar 1,06 A. Jadi dapat dihitung konsumsi daya lampu menggunakan persamaan (4) :

$$
\mathrm{P}=\mathrm{V} \times \mathrm{I}=220 \times 1,06=233,2 \mathrm{~W}
$$

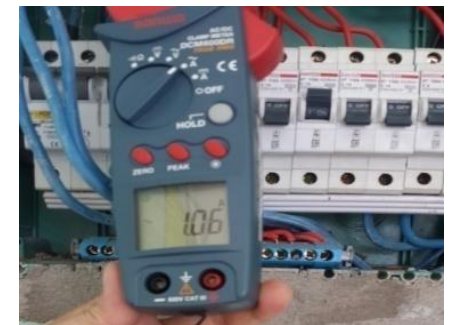

Gambar 1. Hasil Pengukuran Tang Ampere

Pada instalasi listrik terdapat jaringan listrik tiga fasa yang terpasang pada bangunan gedung yang digunakan sebagai aliran listrik penggunaan $\mathrm{AC}$, jalur $\mathrm{R}$ tidak digunakan untuk mensuplai beban $\mathrm{AC}$ di ruang kelas. Pada dua jalur lainnya, berdasarkan hasil pengukuran konsumsi arus beban AC pada jalur S sebesar 5,98 A dan pada jalur T sebesar 5,49 A.

Pada penggunaan arus menggunakan jalur $\mathrm{T}$ dapat dihitung konsumsi daya menggunakan persamaan (4)

$$
\mathrm{P}_{\mathrm{T}}=\mathrm{V} \times \mathrm{I}_{\mathrm{T}}=220 \times 5,49=1.207,8 \mathrm{~W}
$$


Pada penggunaan arus menggunakan jalur $\mathrm{S}$ dapat dihitung konsumsi daya menggunakan persamaan (4)

$\mathrm{P}_{\mathrm{S}}=\mathrm{V} \times \mathrm{I}_{\mathrm{S}}=220 \times 5,98=1.315,6 \mathrm{~W}$

Dari perhitungan daya pada jalur $\mathrm{T}$ dan jalur $\mathrm{S}$ diperoleh total daya yang terpakai untuk AC yaitu $2.523,4 \mathrm{~W}$.

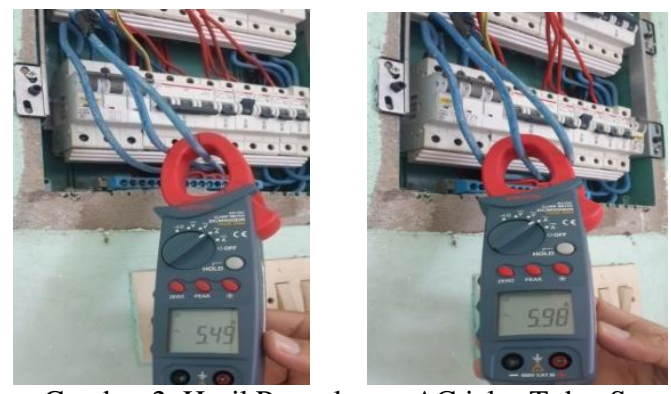

Gambar 2. Hasil Pengukuran AC jalur T dan S

\subsection{Hasil Pengukuran menggunakan Lux meter} dan Hygrometer

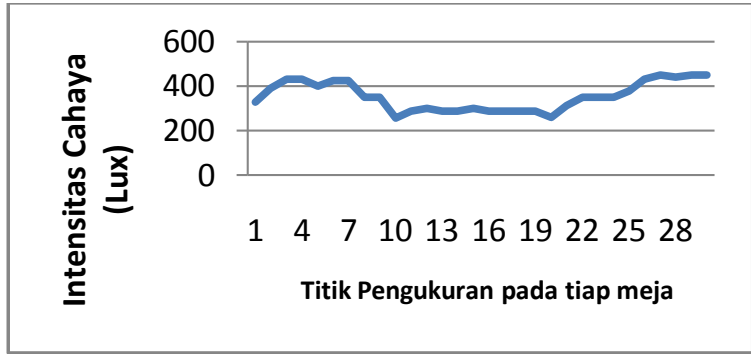

Gambar 3. Pengukuran Intensitas Cahaya Ruang Kelas

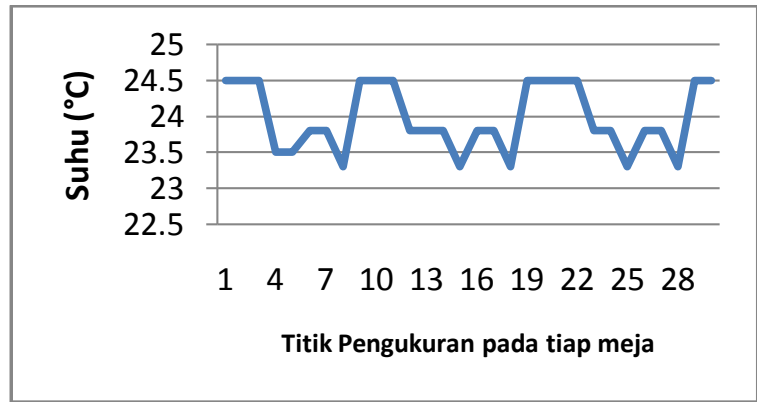

Gambar 4. Pengukuran Suhu Ruang Kelas

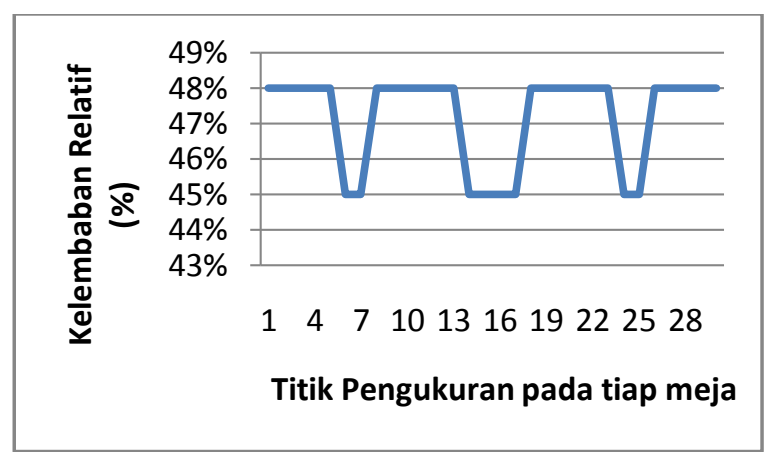

Gambar 5. Pengukuran Kelembaban pada Ruang Kelas

Pengukuran (Gambar 3 - 5) dilakukan pada ruang kelas pada titik-titik pengukuran tertentu seperti yang disajikan pada denah ruangan (lihat Gambar 6) dimana posisi letak lampu diperlihatkan pada Gambar 7.

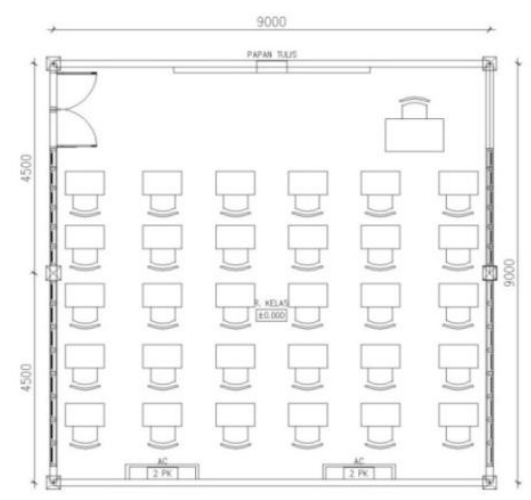

Gambar 6. Denah Ruang Kelas

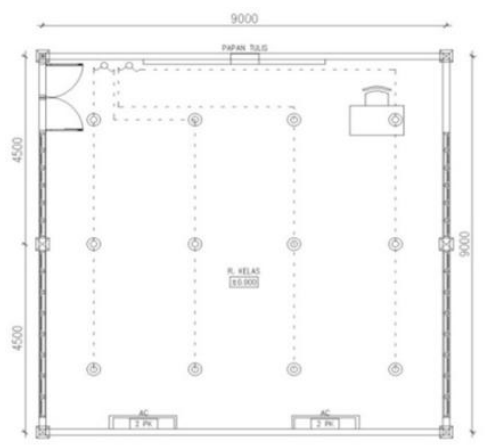

TTTK LAMPU \& SAKLaR

Gambar 7. Denah Posisi Lampu

Dari data yang diperoleh menggunakan lampu dengan daya $20 \mathrm{~W}$ dengan merk HORI, rata-rata intensitas pencahayaan dengan menggunakan lampu yang ada saat ini adalah sebesar 354,63 lux. Berdasarkan Standar Nasional Indonesia (SNI), intensitas ruang kelas adalah 250 lux. Dengan demikian, pada sistem penerangan yang ada saat ini terdapat pemborosan sebesar 104,63 lux.

\subsection{Perhitungan Kebutuhan Cahaya pada Ruang Kelas}

Berikut ini adalah perhitungan kebutuhan cahaya untuk ruangan kelas, dengan diketahui, E rata-rata (standar) penerangan yang dibutuhkan $=250$ lux, $\mathrm{CU}=$ $0,69^{[8,9]}, \mathrm{A}=81 \mathrm{~m}^{2}$, dan $\mathrm{LLF}=0,8^{[3]}$, sesuai SNI maka dari persamaan (2) :

$$
\begin{aligned}
\mathrm{E} & =\frac{\varphi \times \mathrm{CU} \times \mathrm{LLF}}{\mathrm{A}} \\
\varphi & =\frac{\mathrm{E} \times \mathrm{A}}{\mathrm{CU} \times \mathrm{LLF}} \\
& =\frac{250 \times 81}{0,69 \times 0,8}=36.684,78 \text { lumen }
\end{aligned}
$$

Diperoleh total fluks pencahayaan pada area pencahayaan (lumen) sesuai SNI adalah $\mathbf{3 6 . 6 8 4 , 7 8}$ lumen.

Sesuai data pengukuran, dapat dihitung kebutuhan cahaya sebagai berikut dari persamaan (2) 


$$
\begin{aligned}
\varphi & =\frac{\mathrm{E} \times \mathrm{A}}{\mathrm{CU} \times \mathrm{LLF}} \\
& =\frac{354,63 \times 81}{0,69 \times 0,8}=52.038,09 \text { lumen }
\end{aligned}
$$

Diperoleh total fluks pencahayaan pada area pencahayaan ( lumen ) sesuai data pengukuran adalah 52.038,09 lumen.

Dari hasil pengukuran dan SNI terdapat selisih dan ini mengakibatkan pemborosan energi. Berikut perhitungan hasil pemborosan energi yang terjadi menurut persamaan (2) :

$$
\begin{aligned}
\varphi & =\frac{\mathrm{E} \times \mathrm{A}}{\mathrm{CU} \times \mathrm{LLF}} \\
& =\frac{104,63 \times 81}{0,69 \times 0,8}=15.353 \text { lumen }
\end{aligned}
$$

Diperoleh total fluks pencahayaan pada area pencahayaan ( lumen ) sesuai hasil pemborosan energi yang terjadi adalah $\mathbf{1 5 . 3 5 3}$ lumen.

\subsection{Pemodelan Optimasi Penggunaan Energi}

Dari hasil perhitungan tersebut, maka penulis membuat pemodelan matematika dalam bentuk persamaan linear yang dapat menghasilkan penggunaan energi yang lebih optimal.

Dalam hal ini, penggunaan lampu pada ruang kelas berjumlah 12 buah lampu dengan masing-masing lampu mempunyai 4.336,51 lumen. Seharusnya pada kelas dengan luas $81 \mathrm{~m}^{2}$ mempunyai jumlah lumen sebesar 36.684,78 lumen, maka dapat dibentuk persamaan sebagai berikut :

$$
\min \mathrm{P}=\sum_{i=1}^{n} \mathrm{a}_{i} \mathrm{~L}_{i}
$$

dengan kendala :

$$
\begin{aligned}
& \sum_{\mathrm{i}=1}^{\mathrm{n}} l_{i} \mathrm{~L}_{i} \geq 36.684,78 \\
& \sum_{i=1}^{n} \mathrm{a}_{i} \mathrm{~L}_{i} \geq 233,2 \\
& \sum_{i=1}^{n} \mathrm{~L}_{i}=12
\end{aligned}
$$

dimana : $\quad \mathrm{P}=$ total daya

$\mathrm{a}_{\mathrm{i}}=$ macam-macam tipe lampu dengan daya yang berbeda

$l_{i}=$ macam-macam tipe lampu dengan lumen yang berbeda

$\mathrm{L}_{i}=$ jumlah lampu pada masing-masing tipe daya dan lumen

Sesuai dengan persamaan (5) - (8) akan diuji pada keadaan yang ada dengan memisalkan penggunaan tiga tipe lampu Compect Flourensent Lamp (CFL) merk Shinyoku dengan masing-masing 30 Watt, 45 Watt dan 65 Watt sesuai dengan tabel 2. Kendala pada permasalahan minimalisasi ini mengacu pada besar lumen dan jumlah daya yang disarankan serta jumlah lampu yang terpasang pada ruang kelas yaitu 12 buah lampu.

Tabel 2 Daftar efikasi lampu CFL merk Shinyoku

\begin{tabular}{cccc}
\hline No & $\begin{array}{c}\text { Daya } \\
\text { lampu } \\
\text { (watt) }\end{array}$ & $\begin{array}{c}\text { Luminous fluk } \\
\text { lampu (lumen) }\end{array}$ & $\begin{array}{c}\text { Efikasi } \\
\text { (lumen/watt) }\end{array}$ \\
\hline 1 & 15 & 750 & 50 \\
2 & 20 & 1010 & 50,5 \\
3 & 23 & 1275 & 55 \\
4 & 26 & 1300 & 50 \\
$\mathbf{5}$ & $\mathbf{3 0}$ & $\mathbf{1 7 0 0}$ & $\mathbf{5 6 , 6}$ \\
6 & 40 & 2400 & 60 \\
$\mathbf{7}$ & $\mathbf{4 5}$ & $\mathbf{2 7 0 0}$ & $\mathbf{6 0}$ \\
$\mathbf{8}$ & $\mathbf{6 5}$ & $\mathbf{3 2 5 0}$ & $\mathbf{5 0}$ \\
\hline
\end{tabular}

Sehingga diperoleh persamaan sebagai berikut : $\min \mathrm{P}=30 \mathrm{~L}_{1}+45 \mathrm{~L}_{2}+65 \mathrm{~L}_{3}$ dengan kendala :

$$
\begin{aligned}
& 1700 \mathrm{~L}_{1}+2700 \mathrm{~L}_{2}+3250 \mathrm{~L}_{3} \geq 36.684,78 \\
& 30 \mathrm{~L}_{1}+45 \mathrm{~L}_{2}+65 \mathrm{~L}_{3} \geq 233,2 \\
& \mathrm{~L}_{1}+\mathrm{L}_{2}+\mathrm{L}_{3}=12
\end{aligned}
$$

dimana :

$\mathrm{L}_{i}=$ jumlah lampu pada masing-masing tipe daya dan lumen
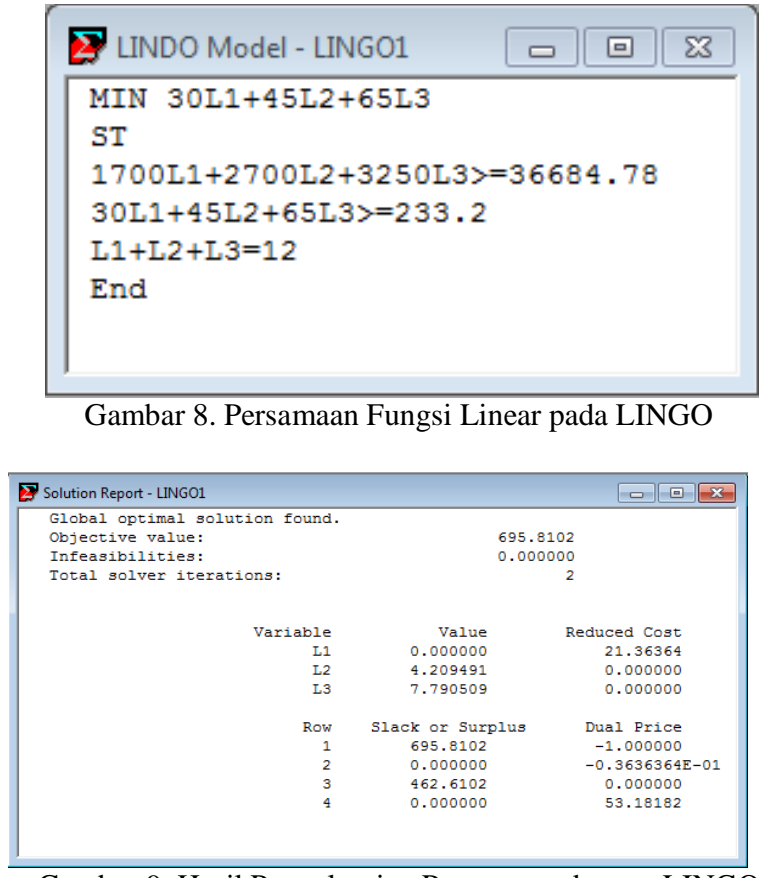

Gambar 9. Hasil Penyelesaian Persamaan dengan LINGO

Penyelesaian persamaan diatas menggunakan aplikasi LINGO sesuai Gambar 8 dan Gambar 9 menghasilkan penggunaan lampu dengan daya 45 Watt sebanyak 4,2 buah dan lampu dengan daya 65 Watt sebanyak 7,8 buah. Penggunaan lampu tidak mungkin dalam bentuk desimal sehingga dibuatlah 2 buah 
pendekatan untuk mendapatkan hasil minimalisasi penggunaan daya yaitu :

a. Pembanding sesuai kendala pertama sebagai berikut :

i. Menggunakan lampu dengan besar intensitas cahaya sebesar 2700 lumen sebanyak 4 lampu dan 3250 lumen sebanyak 8 buah lampu. Hasil yang diperoleh total intensitas cahaya adalah 36.800 lumen.

ii. Menggunaka lampu dengan besar intensitas cahaya sebesar 2700 lumen sebanyak 5 lampu dan 3250 lumen sebanyak 7 buah lampu. Hasil yang diperoleh total intensitas cahaya adalah 36.250 lumen.

b. Pembanding sesuai dengan kendala kedua sebagai berikut :

i. Menggunakan lampu dengan daya 45 Watt sebanyak 4 buah dan lampu dengan daya 65 Watt sebanyak 8 buah. Hasil optimal yang diperoleh dengan lampu tersebut yaitu 700 Watt.

ii. Menggunakan lampu dengan daya 45 Watt sebanyak 5 buah dan lampu dengan daya 65 Watt sebanyak 7 buah. Hasil optimal yang diperoleh dengan lampu tersebut yaitu 680 Watt.

Dari kedua alternatif tersebut diperoleh kombinasi penggunaan lampu dengan daya 45 Watt sebanyak 5 buah dan lampu dengan daya 65 Watt sebanyak 7 buah lebih optimal.

Design posisi lampu ditampilkan pada Gambar 4.8 dengan keterangan $\mathrm{L}_{2}$ adalah lampu dengan daya 45 Watt dan $\mathrm{L}_{3}$ adalah lampu dengan daya 65 Watt.
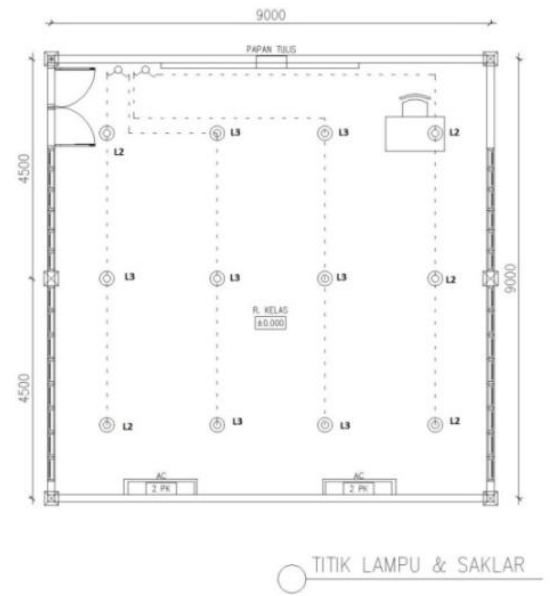

Gambar 10. Denah posisi tipe lampu sesuai daya yang disarankan

\section{Kesimpulan}

a. Dari hasil perhitungan data terukur pada SD Gembala Baik, penggunaan AC pada ruang kelas sudah sesuai dengan standar SNI yang ada, namun tidak demikian dengan intensitas pencahayaan. Terdapat pemborosan pada sistem pencahayaan sebesar 104,63 Lux (Lumen $/ \mathrm{m}^{2}$ ) bedasarkan nilai standar intensitas pencahayaan pada SNI. Berdasarkan total Lumen, penggunaan jumlah lampu dan daya lampu masih belum efisien dikarenakan besar penggunaan 52.038,09 Lumen sedangkan menurut SNI sebaiknya 36.684,78 Lumen, maka terdapat pemborosan energi sebesar 15.353 Lumen.

b. Dari pemodelan optimasi yang dibuat disarankan untuk mengganti lampu yang lebih efisen menggunakan lampu Shinyoku sebanyak 5 buah lampu 45 Watt dan 7 buah lampu 65 Watt untuk menghemat energi.

c. Pemasangan lampu tersebut disarankan menggunakan design sesuai Gambar 4.8 sehingga pencahayaan pada ruang kelas akan lebih baik. 


\section{Referensi}

[1] Badan Standar Nasional. 2001, "Standar Penerangan untuk Ruangan” Standar Nasional Indonesia 03-23962001 .

[2] Badan Standar Nasional 2001, “Standar Pengaturan suhu untuk Ruangan” Standar Nasional Indonesia 036572-2001.

[3] Neidle, Michael. "Teknologi Instalasi Listrik".Jakarta:Penerbit Erlangga.

[4] Muhaimin. 2001. "Tekhnologi Pencahayaan". Bandung: PT. Refika

Aditama.

[5] Badan Standar Nasional 2001, " Tata Cara Perancangan Sistem Pencahayaan Buatan Pada Bangunan Gedung” Standar Nasional Indonesia 03-6575-2001.

[6] Schiler, M, 1992. "Simplified Design Of Building Lighting". John Wiley \& Sons. Inc.

[7] S.D.Panjaitan and Hartoyo,2013, "A lighting control system in buildings based on fuzzy logic", International Journal on Telecommunication, Computing, Electronic and Control (TELKOMNIKA), Vol 9, No. 3, pp. 423432.

[8] Cayless, M.A. and Marsden, A.M. 1983. "Lamps and Lighting : A Manual of Lamps and Lighting $3^{\text {rd }}$ ed".London : Edward Arnold Ltd.

[9] E.W.Mood.Feb 2006. "IES Lighting Handbook ( $3^{\text {rd }}$ ed) The Standart Lighting Guide". America : American Public Health Association.

[10] S.D.Panjaitan and Hartoyo,2012, "Development of Automation System for Room Lighting Based on Fuzzy logic Controller", International Information an Electronics 2 ,No. 6 , November 2012.

\section{Biography}

Mega Sulastri, lahir di Pontianak pada tanggal 12 Oktober 1984. Lulus Sarjana MIPA ( Matematika ) Universitas Gadjah Mada Jogjakarta tahun 2009 dan lulus Pasca Sarjana Teknik Elektro Universitas Tanjungpura Pontianak tahun 2017. Saat ini beraktifitas di SD Plus Gembala Baik Pontianak dan Sekolah Tinggi Manajemen Informatika dan Komputer Widya Dharma Pontianak. 